\title{
EFFECT OF $N$-( $n$-BUTYL)-1,3-DIAMINOPROPANE ON POLYAMINE METABOLISM, CELL GROWTH AND SENSITIVITY TO CHLOROETHYLATING AGENTS
}

\author{
Anthony E. PEgG*† and JAMES K. Coward $\ddagger$ \\ *Departments of Cellular and Molecular Physiology and Pharmacology. Milton S. Hershey Medical \\ Center. Pennsylvania State University College of Medicine. Hershey, PA 17033; and ‡Departments \\ of Chemistry and Medicinal Chemistry. The University of Michigan. Ann Arbor, MI 48109, U.S.A
}

(Received 29 January 1993: accepted 5 April 1993)

\begin{abstract}
The effects of $N$-(n-butyl)-1,3-diaminopropane (BDAP) on cell growth and polyamine content were examined in L1210, SV-3T3 and HT-29 cells. In all cases, BDAP was a specific and highly effective inhibitor of spermine synthesis, and spermine levels were greatly suppressed in the presence of $50 \mu \mathrm{M}$ BDAP. At the same time, there was a parallel increase in spermidine, which equalled or exceeded the fall in spermine so that total polyamine levels were not reduced. Cell growth was not affected in short-term experiments but culture of L1210 cells for $72-144 \mathrm{hr}$ in the presence of BDAP did lead to an effect on growth that was reversed by the addition of spermine. These results suggest that, in the short term, a normal growth rate is maintained by spermidine but that a function or cellular component critically dependent on spermine becomes depleted at longer times. BDAP was a weak inducer of spermidine/spermine- $N^{1}$-acetyltransferase and this enzyme may be responsible for excretion or degradation of the inhibitor. The reduction of spermine produced by BDAP led to a substantial increase in the activity of $S$-adenosylmethionine decarboxylase (AdoMetDC) showing that the repression of this enzyme by spermine is greater than the repression by spermidine. Although higher concentrations were required, BDAP was as effective an inhibitor of spermine synthesis as the mechanism-based inhibitor, $S$-adenosyl-1,12-diamino-3-thio-9-azadodecane (AdoDATAD), and produced similar decreases in spermine and increases in AdoMetDC. Prior treatment of HT-29 human colon carcinoma cells with BDAP increased the killing by chloroethylating agents but to a much smaller extent than the increase brought about by the DNA repair inhibitor. $O^{6}$-benzylguanine. The effect of BDAP is likely to be due to an increased interaction of chloroethylating drugs with nuclear DNA in the absence of spermine since BDAP treatment sensitized cells even in the presence of $O^{6}$-benzylguanine, which prevents repair of these lesions.
\end{abstract}

Polyamines are ubiquitous cellular components that may be necessary for a variety of cellular functions and are clearly essential for cell growth $[1-4]$. Specific inhibitors of enzymes in the polyamine biosynthetic pathway are useful for research into the functions of polyamines and are needed for distinguishing the importance of the individual polyamines, putrescine, spermidine and spermine. In addition, inhibitors of ornithine decarboxylase (ODC) $\$$ and of $S$ adenosylmethionine decarboxylase (AdoMetDC) are useful therapeutic agents for a variety of diseases including trypanosomiasis and cancer [3-6]. Less attention has been given to inhibitors of the aminopropyltransferases capable of blocking either

† Corresponding author: Dr. A. E. Pegg. Department of Cellular and Molecular Physiology, Milton S. Hershey Medical Center. P.O. Box 850. Hershey, PA 17033. Tel. (717) 531-8564; FAX (717) 531-5157.

$\$$ Abbreviations: ODC, ornithine decarboxylase: BDAP. $\mathrm{N}$-( $n$-butyl)-1,3-diaminopropane; AdoMetDC, $S$-adenosylmethionine decarboxylase; AdoDATO, $S$-adenosyl-1,8diamino-3-thiooctane; AdoDATAD, $S$-adenosyl-1,12-diamino-3-thio-9-azadodecane; SAT, spermidine/spermine- $N^{1}$-acetyltransferase; $\mathrm{BE}-3-4-3, \quad N^{1}, N^{12}$-bis(ethyl)spermine; $\mathrm{BCNU}, 1,3$-bis(2-chloroethyl)- $N$-nitrosourea; CCNU, 1-(2-chloroethyl)-3-cyclohexyl-1-nitrosourea; Clomesone, 2-chloroethyl(methylsulfonyl)methanesulfonate; and MTT, 3-(4,5-dimethylthiazol-2-yl)-2,5-diphenyltetrazolium bromide. spermidine synthase or spermine synthase although several potentially useful agents have been described [7-15]. These include $S$-adenosyl-1,8-diamino-3thiooctane (AdoDATO) [7,9,10], cyclohexylamine $[8,11]$ and trans-4-methylcyclohexylamine $[11,12]$ that inhibit spermidine synthase, and $S$-adenosyl1,12-diamino-3-thio-9-azadodecane (AdoDATAD) $[13,14], N$-(n-butyl)-1,3-diaminopropane (BDAP) [15] and $N$-(3-aminopropyl)cyclohexylamine [12] that have been reported to interfere with spermine synthase.

There is a particular need for more information on the effects of inhibition of spermine synthesis. Although all mammalian cells and many lower eukaryotes contain a discrete spermine synthase and, therefore, have levels of spermine comparable to those of spermine. the physiological value of this enzyme is unclear. Many studies have shown that spermidine is needed for growth and spermidine is essential for continued protein synthesis by virtue of its role as a precursor of hypusine, a post-translational modification of initiation factor eIF-5A essential for its activity $[3-6,16,17]$. Spermidine can be replaced by spermine in many of its actions, and addition of spermine to cells whose growth is blocked by addition of inhibitors of ODC or AdoMetDC restores growth but spermine can give rise to spermidine by virtue of the spermidine/spermine- $N^{\prime}$-acetyltransferase (SAT)/polyamine oxidase pathway. Although the 


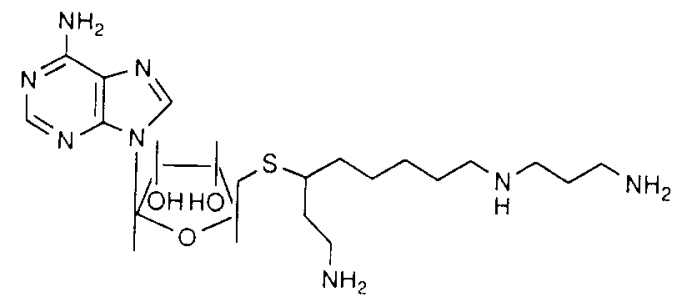

AdoDATAD

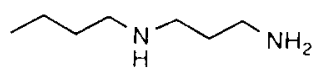

BDAP

Fig. 1. Structures of BDAP and AdoDATAD.

binding of the tetramine, spermine, to nucleic acids and presumably other cellular polyanions is stronger than that of the triamine, spermidine $[18,19]$, there are, at present, no known unique functions for spermine itself. Detailed, long-term studies with inhibitors of spermine synthase may be needed to answer this question.

A number of polyamine analogs are also being considered as potential antineoplastic agents $[3,4,20,21]$. Application of these compounds, of which $N^{1}, N^{12}$-bis(ethyl)spermine (BE-3-4-3) is an example, reduces further normal cellular content dramatically by repressing ODC and AdoMetDC, inducing SAT and causing the excretion of putrescine, spermidine and $N$-acetylated polyamines from the cell [20-24]. Loss of spermine is brought about by such analogs but occurs less readily since spermine itself is not excreted and its disposal appears to require the action of SAT $[21,24]$. Reduction of the initial spermine content may allow the analogs to be employed more effectively.

In the experiments reported in this paper, we studied the effects of BDAP on polyamine levels and cell growth in a number of mammalian cell lines and compared its effects with those of AdoDATAD. The structures of these compounds are shown in Fig. 1.

We also examined the effects of BDAP-induced spermine depletion on the sensitivity of tumor cells to certain alkylating agents. It is known that depletion of putrescine and spermidine brought about by treatment with $\alpha$-diffuoromethylornithine, an ODC inhibitor, renders cells more susceptible to killing by 1,3-bis(2-chloroethyl)- $N$-nitrosourea (BCNU) $[25,26]$. Although the mechanism underlying this effect is not clear, it presumably relates to a change in the content or persistence of the lesions resulting from interaction of the alkylating agent with DNA. We used BDAP to determine whether depletion of spermine may produce a similar type of effect.

\section{MATERIALS AND METHODS}

Materials. S-Adenosyl-L-[carboxy- ${ }^{1+} \mathrm{C} \mid$ methionine $(47.8 \mathrm{mCi} / \mathrm{mmol})$ was purchased from NEN. $\left[{ }^{1+} \mathrm{C}\right]-$ Acetyl-CoA ( $55 \mathrm{mCi} / \mathrm{mmol}$ ) was obtained from ICN. AdoDATAD and BDAP were synthesized as described in Refs. 13 and 15 , respectively. Polyamines and other biochemical reagents were obtained from Sigma. BE-3-4-3 was provided by Dr. R. J. Bergeron, Department of Medicinal Chemistry, University of Florida, Gainesville, FL. 1-(2-Chloroethyl)-3cyclohexyl-1-nitrosourea (CCNU) (NSC 79037) and 2-chloroethyl (methylsulfonyl)methanesulfonate (Clomesone) (NSC 33847) were obtained from the Drug Synthesis and Chemistry Branch, Division of Cancer Treatment. National Cancer Institute, Bethesda. MD.

Cell culture. The source of the cells and the culture conditions have been described previously for HT29 cells [24], SV-3T3 cells [27. 28] and L 1210 cells [17].

Enzyme assays. AdoMetDC was assayed by measuring the production of ${ }^{14} \mathrm{CO}_{2}$ from $S$-adenosyl$\mathrm{L}-\left[\right.$ carboxy- $\left.{ }^{14} \mathrm{C}\right]$ methionine $[29,30]$. SAT was assayed by determining the conversion of $\left[{ }^{1+} \mathrm{C}\right]$ acetyl-CoA into $\left[{ }^{14} \mathrm{C}\right]$ acetyl-spermidine as described [24].

Polyamine and BDAP analysis. Cells were harvested by centrifugation and washed twice with ice-cold phosphate-buffered saline. The washed cell pellet was resuspended in $10 \%(\mathrm{w} / \mathrm{v})$ trichloroacetic acid, the protein precipitate was removed by centrifugation, and the supernatant was filtered $(0.22 \mu \mathrm{m})$ before reversed-phase HPLC analysis to separate BDAP, putrescine, spermidine, and spermine. Post-column derivatization with $o$-phthalaldehyde and fluorescence detection was used to quantitate the polyamines [17]. Cell protein was measured by the method of Bradford [31]. Polyamine content was expressed per milligram of total cell protein.

Effects of chloroethylating agents. The effects on killing by alkylating agents were determined by assaying either colony-forming efficiency or cytotoxicity as follows. Cell colony-forming efficiency after treatment with BDAP was determined by plating HT-29 cells at a density of $0.25 \times 10^{6}$ cells/ $25 \mathrm{~cm}^{2}$ flask. Four hours later BDAP was added to some flasks, and after a further $92 \mathrm{hr}$, the medium was replaced with fresh medium containing various concentrations of either CCNU or Clomesone for $2 \mathrm{hr}$ at $37^{\circ}$. The medium was then replaced with the same medium as that used for the pretreatment for an additional $18 \mathrm{hr}$, and the cells were re-plated at densities between 100 and 3200 per $25 \mathrm{~cm}^{2}$ flask. The cells were allowed to grow for 10-12 days, and colonies were then washed with $0.9 \%$ saline, stained with $0.5 \%$ crystal violet in ethanol, and counted. Results were expressed as the percentage of colonies present when no chloroethylating agent was added. Cytotoxicity was evaluated using modifications of the 3-(4,5-dimethylthiazol-2-yl)-2,5-diphenyltetrazolium bromide (MTT) assay [32]. Cells were plated at a density of 500 cells/well in 96-well plates, allowed to grow and treated with chloroethylating agents as described above. Five days after drug treatment, $25 \mu \mathrm{L}$ of a $5 \mathrm{mg} / \mathrm{mL}$ solution of MTT was 
Table 1. Effect of BDAP on polyamines in human and rodent cells

\begin{tabular}{|c|c|c|c|c|}
\hline \multirow[b]{2}{*}{ Treatment and cells } & \multicolumn{4}{|c|}{ Polyamine content ( $\mathrm{nmol} / \mathrm{mg}$ protein) } \\
\hline & Putrescine & Spermidine & Spermine & Total \\
\hline SV-3T3 $48 \mathrm{hr}$ & $4.0 \pm 0.2$ & $27.8 \pm 0.4$ & $14.0 \pm 0.9$ & 45.8 \\
\hline SV-3T3 $72 \mathrm{hr}$ & $7.4 \pm 1.1$ & $26.9 \pm 2.2$ & $13.9 \pm 1.7$ & 48.2 \\
\hline $\mathrm{SV}-3 \mathrm{~T} 3+50 \mu \mathrm{M}$ BDAP, $48 \mathrm{hr}$ & $0.4 \pm 0.3$ & $48.3 \pm 8.7$ & $3.5 \pm 0.5$ & 52.2 \\
\hline $\begin{array}{l}\text { SV }-3 T 3+50 \mu \mathrm{M} \text { BDAP, } 72 \mathrm{hr} \\
\text { SV }-3 \mathrm{~T} 3+50 \mu \mathrm{M} \text { BDAP, } 72 \mathrm{hr}+\end{array}$ & $0.8 \pm 0.2$ & $47.1 \pm 3.5$ & $2.4 \pm 0.2$ & 50.3 \\
\hline $25 \mu \mathrm{M}$ BE-3-4-3, $24 \mathrm{hr}$ & $0.4 \pm 0.3$ & $6.4 \pm 0.5$ & $1.5 \pm 0.1$ & 8.3 \\
\hline $\mathrm{SV}-3 \mathrm{~T} 3+25 \mu \mathrm{M}$ BE$-3-4-3,24 \mathrm{hr}$ & $0.2 \pm 0.1$ & $3.0 \pm 0.2$ & $8.7 \pm 0.4$ & 11.9 \\
\hline $\mathrm{HT}-29,48 \mathrm{hr}$ & $9.0 \pm 2.2$ & $16.7 \pm 3.1$ & $24.2 \pm 3.5$ & 49.9 \\
\hline HT. $29,72 \mathrm{hr}$ & $4.4 \pm 1.2$ & $12.0 \pm 2.1$ & $22.4 \pm 4.2$ & 38.8 \\
\hline HT $-29+50 \mu \mathrm{M}$ BDAP, $48 \mathrm{hr}$ & $0.7 \pm 0.2$ & $43.3 \pm 6.1$ & $5.6 \pm 0.2$ & 49.6 \\
\hline $\begin{array}{l}\text { HT }-29+50 \mu \mathrm{M} \text { BDAP, } 72 \mathrm{hr} \\
\text { HT }-29+50 \mu \mathrm{M} \text { BDAP, } 72 \mathrm{hr}+\end{array}$ & $0.2 \pm 0.1$ & $37.7 \pm 2.8$ & $5.9 \pm 0.6$ & 43.8 \\
\hline $25 \mu \mathrm{M} \mathrm{BE}-3-4-3,24 \mathrm{hr}$ & $<0.1$ & $7.9 \pm 0.7$ & $4.8 \pm 0.7$ & 12.7 \\
\hline $\mathrm{HT}-29+25 \mu \mathrm{M}$ BE$-3-4-3,24 \mathrm{hr}$ & $<0.1$ & $2.8 \pm 0.4$ & $11.3 \pm 1.0$ & 14.1 \\
\hline $\mathrm{L} 1210,48 \mathrm{hr}$ & $3.0 \pm 0.4$ & $20.1 \pm 2.1$ & $9.9 \pm 0.6$ & 33.0 \\
\hline L1210, $72 \mathrm{hr}$ & $1.9 \pm 0.4$ & $24.1 \pm 2.5$ & $9.4 \pm 0.7$ & 35.4 \\
\hline L1210 + $50 \mu \mathrm{M}$ BDAP. $48 \mathrm{hr}$ & $0.4 \pm 0.2$ & $28.3 \pm 6.1$ & $2.1 \pm 0.2$ & 30.8 \\
\hline $\begin{array}{l}\mathrm{L} 1210+50 \mu \mathrm{M} \text { BDAP, } 72 \mathrm{hr} \\
\\
21210+50 \mu \mathrm{MPAP}\end{array} 2 \mathrm{hr}+$ & $1.4 \pm 0.4$ & $31.5 \pm 2.3$ & $1.4 \pm 0.3$ & 34.3 \\
\hline $25 \mu \mathrm{M}$ BE-3-4-3, $24 \mathrm{hr}$ & $<0.1$ & $6.1 \pm 0.1$ & $1.2 \pm 0.1$ & 7.3 \\
\hline $\mathrm{L} 1210+25 \mu \mathrm{M}$ BE $-3-4-3,24 \mathrm{hr}$ & $<0.1$ & $2.6 \pm 0.2$ & $6.0 \pm 0.2$ & 8.6 \\
\hline
\end{tabular}

BDAP was added at $4 \mathrm{hr}$ after plating and the cells were grown for the time shown. BE-3-4-3 was added after $48 \mathrm{hr}$ of culture and the cells were harvested $24 \mathrm{hr}$ later. Results are the means \pm SD for at least 4 estimations.

added to each well followed 2 hr later by the addition of $100 \mu \mathrm{L}$ lysing buffer, $\mathrm{pH} 4.7$ (20\% sodium dodecyl sulfate, $50 \% \mathrm{~N}, \mathrm{~N}$-dimethylformamide and $0.8 \%$ acetic acid) for an additional $22 \mathrm{hr}$. A microplate reader set at $570 \mathrm{~nm}$ was used to determine the absorbance. The number of cells killed was then determined as the fraction of the optical density seen in the cells treated with vehicle alone.

\section{RESULTS}

Depletion of spermine by BDAP. Addition of $50 \mu \mathrm{M}$ BDAP to the culture medium led to a marked depletion of spermine (by about $80 \%$ ) within 48$72 \mathrm{hr}$ in several different mammalian cell lines, virally transformed mouse fibroblasts (SV-3T3), mouse leukemia cells (L1210) and human colon carcinoma cells (HT-29) (Table 1). At the same time, there was an increase in cellular spermidine. This is consistent with BDAP blocking the spermine synthase step of polyamine biosynthesis. Because of the compensatory increase in spermidine, there was no decrease in total polyamine content. This total remained the same in L1210 cells, increased slightly in SV-3T3, and increased to a greater extent at $72 \mathrm{hr}$ in HT-29 cells. Exposure to BDAP also markedly reduced the content of putrescine in all three cell lines (Table 1). Despite the large decrease in spermine, there was no effect of BDAP on growth of these cells over the $72-\mathrm{hr}$ period tested (results not shown).

When cells were treated with BE-3-4-3, there was a profound drop in the concentrations of all of the polyamines, although spermine was affected to the

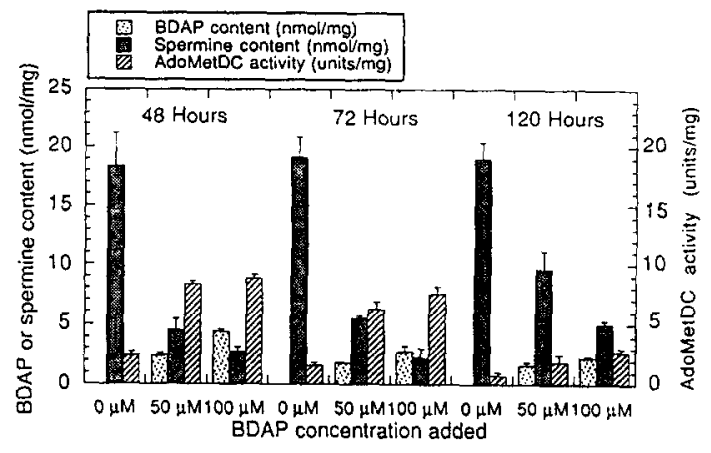

Fig. 2. Effect of BDAP on spermine and AdoMetDC in HT-29 cells. The HT-29 cells were grown in the presence of 0,50 or $100 \mu \mathrm{M}$ BDAP for 48,72 or $120 \mathrm{hr}$ as indicated. The content of spermine and BDAP and the activity of AdoMetDC were then measured in extracts as described under Materials and Methods. Results are the means \pm SD for at least 4 estimations.

least extent (Table 1). The combination of BDAP with BE-3-4-3 slightly increased the total extent of polyamine depletion and markedly reduced cellular spermine but there was again a parallel increase in spermidine.

A slightly greater effect on spermine levels $(85 \%$ reduction) was achieved using $100 \mu \mathrm{M}$ BDAP rather than $50 \mu \mathrm{M}$ in HT-29 cells for $48 \mathrm{hr}$ (Fig. 2). The higher level of BDAP was reflected in the intracellular BDAP content which almost doubled with the higher 


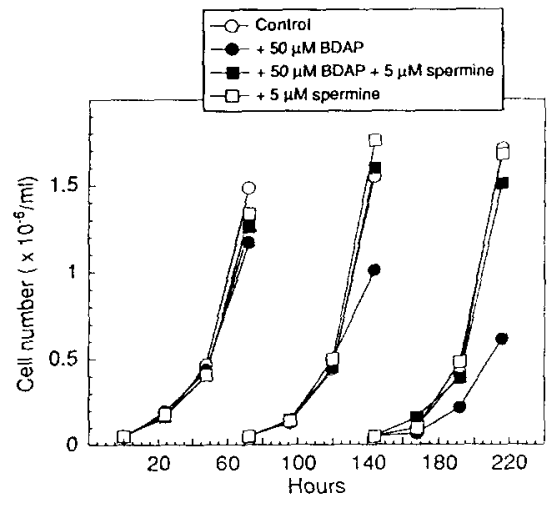

Fig. 3. Spermine-mediated reversal of L1210 cell growth inhibition by BDAP. L1210 cells were seeded at a density of $10^{6}$ cells $/ \mathrm{mL}$ and allowed to grow for $72 \mathrm{hr}$ in the presence of $50 \mu \mathrm{M}$ BDAP and/or $5 \mu \mathrm{M}$ spermine as shown. The cells were then re-seeded at the starting density in the same medium and grown for a further $72 \mathrm{hr}$. The procedure was then repeated for a third time. All cultures contained $1 \mathrm{mM}$ aminoguanidine to prevent conversion of the added spermine to toxic oxidation products.

dose. The reduction in spermine was not increased by further exposure to BDAP for up to $120 \mathrm{hr}$, and it appears that the effects may be slightly less by $120 \mathrm{hr}$. At this time point, the reduction in spermine was only $50 \%$ with $50 \mu \mathrm{M}$ BDAP and $74 \%$ with $100 \mu \mathrm{M}$. This may be due to the fact that the cellular content of BDAP actually fell slightly with time (Fig. 2 ), and it is possible that the inhibitor was degraded or excreted.

Effects of BDAP on cell growth. Although in short-term experiments of up to 72-hr exposure, there was no effect of BDAP-mediated spermine depletion on cell growth, this may not be the case at longer times. In HT-29 cells treated for $120 \mathrm{hr}$. growth was reduced by $22 \%$ at $50 \mu \mathrm{M}$ BDAP and by $30 \%$ with $100 \mu \mathrm{M}$ (results not shown).

Longer term effects on growth were, therefore, examined more fully in L 1210 cells by re-seeding the treated cells into the medium containing $50 \mu \mathrm{M}$ BDAP so that growth and effects on polyamines could be tested over a period of $220 \mathrm{hr}$. As shown in Fig. 3, an inhibitory effect on growth became apparent at times after $144 \mathrm{hr}_{\text {, }}$ and this effect was prevented completely by providing $5 \mu \mathrm{M}$ spermine. Addition of $5 \mu \mathrm{M}$ spermine to the culture medium also completely overcame the BDAP-mediated depletion of spermine in the cells at $72 \mathrm{hr}$ (results not shown) and at $144 \mathrm{hr}$ (Table 2). There was no change in the intracellular level of BDAP when spermine was added (Table 2), showing that the reversal of the effect on growth was not due to a change in uptake of the inhibitor. Similar experiments carried out with D-R cells (DFMO-resistant variants of L1210 that have 100 times higher ODC activities and much higher putrescine and slightly higher spermine contents when grown in the absence of DFMO [33]) showed exactly the same results (not shown).
Induction of spermidine/spermine $\mathrm{N}^{1}$-acetyltransferase (SAT) by BDAP. Many polyamine analogs have been shown to act as inducers of SAT. Since SAT activity is linked to the degradation of polyamines and their excretion from the cell, such induction can contribute significantly to the effects of such analogs on cellular polyamine content [21]. However, as shown in Table 3, BDAP was only weakly active in inducing SAT, giving a 3- to 4-fold increase as opposed to the more than 100-fold rise in activity produced by a powerful inducer such as $\mathrm{BE}-3-4-3[20-24]$. It is therefore unlikely that much of the effect of BDAP on polyamines is due to an increase in polyamine acetylation. However, the induction of SAT could play a role in the reduction of BDAP levels at prolonged incubation times (Fig. 2). since BDAP is a weak substrate for SAT (Pegg $\mathrm{AE}$ and Albanese L, unpublished observations).

Effect of BDAP on AdoMetDC. Previous work has shown that the cellular activity of AdoMetDC is negatively affected by the polyamine content $[29,30,34,35$ and references therein]. As shown in Fig. 2, the activity of AdoMetDC was increased 3to 5-fold in HT-29 cells treated with BDAP. This increase correlated with the decline in spermine

Comparison of BDAP with AdoDATAD. Overall. the results described above are compatible with BDAP being a relatively specific inhibitor of spermine synthase leading to an increase in spermidine because of its lack of conversion to spermine. These results suggest that BDAP, which is much casier to synthesize than AdoDATAD. may be as effective and specific as an inhibitor of spermine formation. Direct comparisons in L1210 and HT-29 cells suggest that this is indeed the case (Table 4). The percentage changes in spermine. spermidine and AdoMetDC were indistinguishable when these inhibitors were compared. The only difference was in the content of putrescine, which was reduced more effectively by BDAP.

Effects of BDAP on the susceptibility of $H T-29$ cells to chloroethylating agents. It has been reported by Marton and colleagues $[25,26]$ that exposure of cells to inhibitors of ODC increases the sensitivity of some tumor cell lines to killing by chloroethylating drugs. The effect of depletion of spermine by BDAP and AdoDATAD on the sensitivity of HT- 29 cells to these agents was tested by treating the cells for $2 \mathrm{hr}$ with either CCNU or Clomesone. After a further $18 \mathrm{hr}$ in the presence of the sperminesunthase inhibitors to allow for the conversion of the initial DNA adducts to interstrand cross-links. the cell killing was measured using either a colonyforming assay (Fig. 4) or a cytotoxicity assay (Fig. 5). Two different assays were used to ensure that the results were not biased by the assay method. Using the colony-forming assay, it was found that BDAP did enhance killing of HT-29 cells by CCNU or by Clomesone and that this could be prevented by providing spermine (Fig. 4). A limited study with AdoDATAD also showed a similar enhancement of the effects of Clomesone (results not shown), but these experiments were limited by the small amount of drug available and the inhibition of cell plating by the drug itself. The cytotoxicity assays confirmed 
Table 2. Effect of BDAP and spermine on polyamines in L1210 cells

\begin{tabular}{lccccc}
\hline & \multicolumn{5}{c}{ Polyamine content (nmol/mg protein) } \\
\cline { 2 - 6 } \multicolumn{1}{c}{ Treatment } & Putrescine & Spermidine & Spermine & Total & BDAP \\
\hline None. 144 hr & $2.7 \pm 0.5$ & $22.9 \pm 3.2$ & $10.9 \pm 1.7$ & 36.5 & 0.0 \\
$50 \mu \mathrm{M}$ BDAP. 144 hr & $1.4 \pm 0.4$ & $28.1 \pm 5.9$ & $1.3 \pm 0.3$ & 30.8 & $7.9 \pm 1.7$ \\
$50 \mu \mathrm{M}$ BDAP + & $2.4 \pm 0.11$ & $23.5 \pm 1.6$ & $9.5 \pm 1.9$ & 35.4 & $8.5 \pm 1.2$ \\
$5 \mu \mathrm{M}$ spermine. 144 hr & 2.4 &
\end{tabular}

Results are the means \pm SD for at least 4 estimations.

Table 3. Effect of BDAP on SAT in SV-3T3 cells

\begin{tabular}{lcc}
\hline & \multicolumn{2}{c}{ SAT activity (units/mg protein) } \\
\cline { 2 - 3 } \multicolumn{1}{c}{ Treatment } & $48 \mathrm{hr}$ & $72 \mathrm{hr}$ \\
\hline None & $4.5 \pm 0.6$ & $2.2 \pm 0.2$ \\
$50 \mu \mathrm{M}$ BDAP & $12.2 \pm 0.6$ & $7.9 \pm 1.3$ \\
$25 \mu \mathrm{M}$ BE-3-4-3 & $333 \pm 47$ & $548 \pm 33$ \\
\hline
\end{tabular}

Activity was measured after exposure to the drugs for the time shown. Results are the means \pm SD for at least 4 estimations.

that there was an increased killing of BDAP-treated cells (Fig. 5).

HT-29 cells have a high content of $O^{6}$-alkylguanineDNA alkyltransferase which strongly protects against chloroethylating drugs by removing initial monoadducts formed in DNA before they rearrange to form lethal cross-links [36.37]. The alkyltransferase activity can be depleted by use of $O^{6}$. benzylguanine [33], and such depletion is known to have a very large effect on the killing of HT-29 cells by chloroethylating agents $[38,39]$. Therefore, the possible interaction between $O^{6}$-benzylguanine and BDAP was tested. Treatment with $O^{6}$-benzylguanine had the expected result, increasing cytotoxicity substantially (Fig. 5). BDAP increased cell killing to a smaller extent but was effective in the presence or absence of $O^{6}$-benzylguanine, suggesting that the effects of spermine depletion were not mediated by changes in DNA repair during the period after treatment with the chloroethylating agents (Fig. 5).

\section{DISCUSSION}

BDAP was reported to be a potent inhibitor of spermine synthase in vitro [15], and the present results using several cell lines confirm that it can be used to prevent spermine production in mammalian cells. Although the three cell types used in the present experiments have very different spermidine to spermine ratios, exposure to BDAP brought about a substantial decline in spermine in all of them. In fact, the $80 \%$ decline in spermine seen in response to BDAP is consistent with an almost complete block at the spermine synthase step. Spermine degradation and excretion occur to only a very limited extent in these cell cultures so the decline in spermine is brought about by the increase in cell number under conditions in which spermine synthesis is prevented.

General problems with biochemical and pharmacological studies using inhibitors include the difficulty in establishing the specificity of the effects and the possible lack of uptake and/or stability of

Table 4. Comparison of BDAP and AdoDATAD in inhibition of spermine synthesis and stimulation of AdoMetDC

\begin{tabular}{lcccc}
\hline & \multicolumn{3}{c}{ Effect on polyamines or AdoMetDC (\% of control) } \\
\cline { 2 - 5 } \multicolumn{1}{c}{ Cells and treatment } & Putrescine & Spermidine & Spermine & AdoMetDC \\
\hline HT-29 cells, 50 $\mu \mathrm{M}$ BDAP, 48 hr & 8 & 217 & 16 & 410 \\
HT-29 cells, 20 $\mu \mathrm{M}$ AdoDATAD, 48 hr & 49 & 226 & 19 & 484 \\
HT-29 cells, 50 $\mu \mathrm{M}$ BDAP, 72 hr & 5 & 236 & 18 & 495 \\
HT-29 cells, 20 $\mu \mathrm{M}$ AdoDATAD, 72 hr & 70 & 221 & 21 & 382 \\
L1210 cells, 50 $\mu \mathrm{M}$ BDAP, 48 hr & 13 & 141 & 21 & ND \\
L1210 cells, 20 $\mu \mathrm{M}$ AdoDATAD, 48 hr & 73 & 160 & 22 & ND \\
L1210 cells, 50 $\mu \mathrm{M}$ BDAP, 72 hr & 76 & 136 & 15 & ND \\
L1210 cells, 20 $\mu \mathrm{M}$ AdoDATAD, 72 hr & 83 & 128 & 22 & ND \\
\hline
\end{tabular}

Results are the means of three separate experiments. The absolute values for control cell polyamines are given in Table 1 and for AdoMetDC in Fig. 2.

* ND, not determined. 

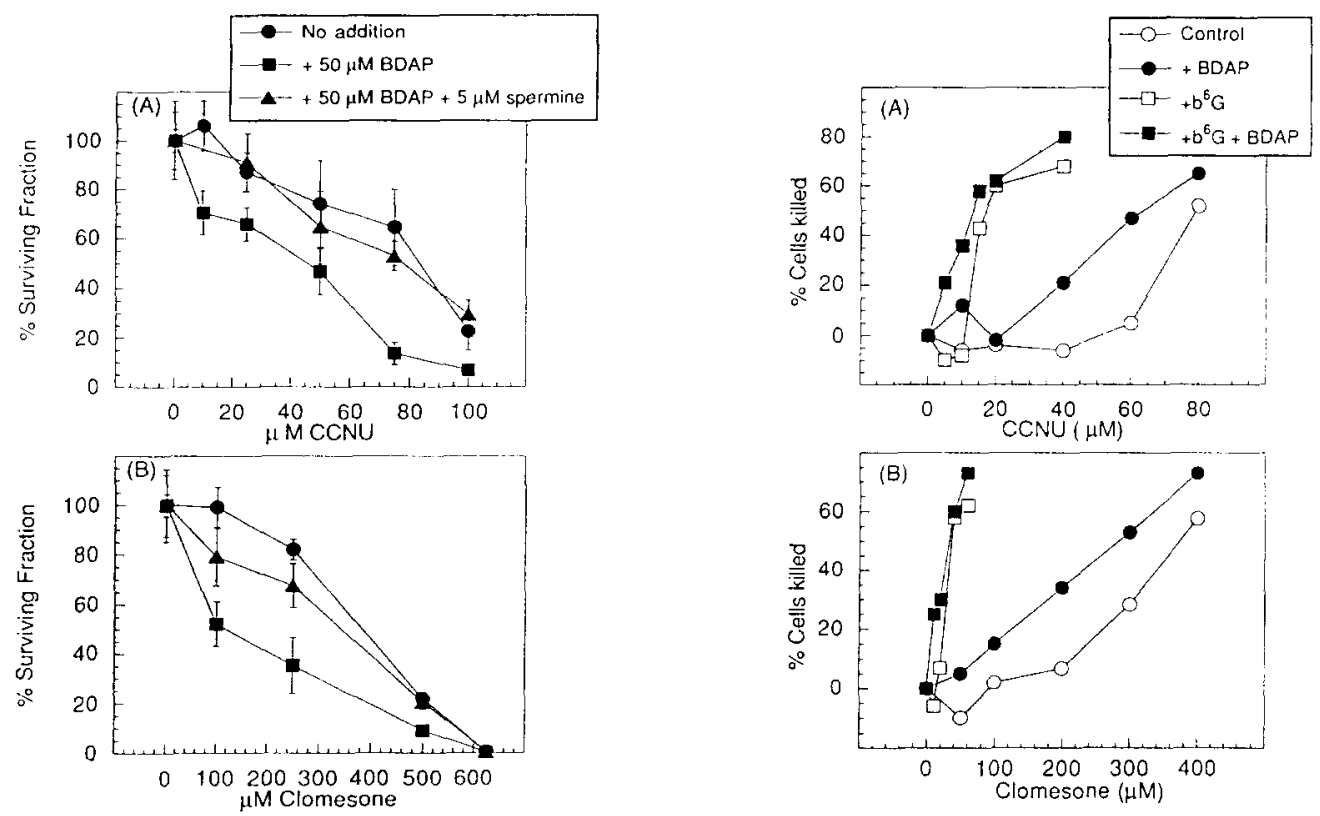

Fig. 4. Effect of BDAP and spermine on killing of HT-29 cells by chloroethylating agents. HT-29 cells were treated with $50 \mu \mathrm{M}$ BDAP and/or $5 \mu \mathrm{M}$ spermine as shown for $88 \mathrm{hr}$ and then exposed to CCNU (upper panel) or Clomesone (lower panel) at the concentrations indicated. Colony-forming assays were then carried out as described under Materials and Methods, and the percentage survival was calculated. Results are the means \pm SD for at least 4 estimations.

Fig. 5. Effect of BDAP and $O^{6}$-benzylguanine on killing of HT-29 cells by chloroethylating agents. HT-29 cells were treated as shown with $50 \mu \mathrm{M}$ BDAP for $92 \mathrm{hr}$ and/or with $25 \mu \mathrm{M} O^{6}$-benzylguanine $\left(\mathrm{b}^{6} \mathrm{G}\right)$ for $2 \mathrm{hr}$ and then exposed to CCNU (upper panel) or Clomesone (lower panel) at the concentrations indicated. Cell killing was then determined using the MTT assay. Results are expressed as the percentage of cells killed compared with the cells treated with no chloroethylating agent. Further details of the number of cells plated are given under Materials and Methods. Results are the means of at least 4 assays that agreed within $\pm 5 \%$.

the inhibitors. Since the structure of BDAP is very different from that of the nucleoside spermine synthase inhibitor AdoDATAD [13] (Fig. 1), the two compounds provide a useful pair to evaluate the effects of spermine. Both inhibitors are clearly superior to other compounds used to block spermine production such as dimethyl( $5^{\prime}$-adenosyl)sulfonium salt [27-29]. The availability of BDAP to complement studies with AdoDATAD should make it easier to establish that effects are due to perturbation of polyamine levels. Also, since BDAP is easier to synthesize than AdoDATAD and is not likely to interact with adenosine receptors, it may be more suitable for long-term studies in intact animals.

It should be noted, however, that the results shown in Fig. 2 suggest that the induction of resistance to BDAP may reduce its effectiveness slightly and necessitate higher doses for prolonged exposure. The decreased effectiveness of BDAP at later time points appears to be due to a diminished intracellular level of BDAP but the means by which this reduction is brought about are unclear. One possibility is the induction of SAT by BDAP followed by the acetylation of the compound by this enzyme. SAT activity in mammalian cells is normally very low but can be increased greatly in response to a variety of stimuli including treatment with polyamine analogs [20-24]. Although BDAP was much less active than BE-3-4-3 as an SAT inducer (Table 3), activity was increased. The general structural

requirement for substrates that can be acetylated by SAT is the presence of an aminopropyl group attached to another $\mathrm{N}$ atom [i.e. $\mathrm{H}_{2} \mathrm{~N}\left(\mathrm{CH}_{2}\right)_{3} \mathrm{NH}-\mathrm{R}$ ] [21]. BDAP has a suitable structure and is acetylated by SAT, albeit at a rate less than $1 \%$ that of spermidine (Pegg AE and Albanese $\mathrm{L}$, unpublished observations). In general, acetylation of polyamines leads to further degradation and/or excretion from the cell [21] so the involvement of SAT in reduction of BDAP levels by this mechanism is a plausible hypothesis.

In addition to its effect on spermine levels, exposure to BDAP leads to a substantial increase in AdoMetDC activity. It is well known that AdoMetDC is repressed by both spermidine and spermine $[30,34,35]$. The results with BDAP are in agreement with this concept. Furthermore, they show that spermine is more effective than spermidine in this respect, since there was an increase in spermidine comparable with the decline in spermine in BDAPtreated cells.

The only major difference between the results of exposure to BDAP and to AdoDATAD was that putrescine levels were much lower in cells exposed to BDAP (Table 4). The decline in putrescine in response to AdoDATAD may be due to the fact that spermidine is a better repressor of ODC than 
spermine and/or to the increase in AdoMetDC activity that provides more substrate to convert putrescine into spermidine $[3,4,30,35,40]$. However, this can explain only part of the decline in putrescine when BDAP is used since AdoMetDC levels increased and ODC levels declined to the same extent with both AdoDATAD and BDAP (results not shown). The possibility that BDAP and putrescine compete for an uptake system and that BDAP causes an efflux of putrescine from the cell is suggested by these results.

Depletion of spermine by BDAP had no effect on growth in short-term experiments. This is in agreement with several other studies showing that inhibition of spermine synthesis does not influence cell growth $[14,15,27-30]$, but it is premature to conclude that spermine does not play a vital role in mammalian cellular metabolism. As shown in Fig. 3 . longer term exposures may have more marked effects, and recent results [17] have shown that spermine is more effective than spermidine in reversing the cytostatic effects of inhibitors of AdoMetDC. This cytostasis does not become apparent until 12 days of elimination of AdoMetDC activity [17].

Although short-term exposures to BDAP had no effect on growth, the compound (and other spermine synthase inhibitors) may be useful in modifying the effects of other agents. First, since spermidine is more readily depleted in cells exposed to polyamine analogs than spermine, the use of a spermine synthase inhibitor may make it easier to deplete polyamines in vivo using analogs such as BE-3-4-3. However, as shown in Table 1 , in cell culture even the analogs alone were effective. Second, in HT-29 tumor cells, exposure to BDAP increased the killing by chloroethylating agents. This effect is likely to result from an increased level of DNA damage rather than a decreased rate of repair since it occurred in the presence of $O^{6}$-benzylguanine, a drug known to block repair of the initial DNA lesions that then go on to form lethal cross-links [36-39]. The effect of BDAP was reversed by spermine, and it is possible that the change in spermine levels renders some sites in chromatin more available to interact with the drugs. This suggests that spermine depletion may be useful as treatment with ODC inhibitors [25] in increasing the effects of chloroethylating agents. However, it should be cautioned that this effect may be dependent on the tumor cell type involved. HT29 cells have very high levels of spermine and a high spermine:spermidine ratio (Table 1), and this may influence their response to such drug combinations.

Acknowledgements-This research was supported by Grants CA-37606 and GM-26290 from the National Institutes of Health. We thank Drs. Chin Liu and Patrick Woster for the synthesis of BDAP and AdoDATAD. respectively.

\section{REFERENCES}

1. Pegg AE and McCann PP, Polyamine metabolism and function. Am J Physiol 243: C212-C221, 1982.

2. Tabor CW and Tabor H, Polyamines. Annu Rev Biochem 53: 749-790, 1984.
3. Pegg AE, Recent advances in the biochemistry of polyamines in eukaryotes. Biochem $J$ 234: 249-262, 1986.

4. Jänne J. Alhonen L and Leinonen P. Polyamines: From molecular biology to clinical applications. Ann Med 23: $241-259,1991$.

5. McCann PP. Pegg AE and Sjoerdsma A (Eds.), Inhibition of Polvamine Metabolism: Biological Significance and Basis for New Therapies, pp. 1-371. Academic Press. New York, 1987.

6. Pegg AE. Polyamine metabolism and its importance in neoplastic growth and as a target for chemotherapy. Cancer Res 48: 759-774, 1988.

7. Coward JK and Pegg AE. Specific multisubstrate adduct inhibitors of aminopropyltransferases and their effect on polyamine biosynthesis in cultured cells. $A d v$ Enzyme Regul 26: 107-113. 1987.

8. Hibasami H. Tanaka M. Nagai J and Ikeda $T$. Dicyclohexylamine. a potent inhibitor of spermidine synthase in mammalian cells. FEBS Lett 116: 99-101. 1980.

9. Tang KC. Mariuzza R and Coward JK. Synthesis and evaluation of some stable multisubstrate adducts as specific inhibitors of spermidine synthase. $J$ Med Chem 24: $1277-1284,1981$

10. Pegg AE, Tang KC and Coward JK. Effect of $S$ adenosyl-1,8-diamino-3-thiooctane on polyamine metabolism. Biochemistry 21: 5082-5089, 1982.

11. Shirahata A, Morohoshi T and Samejima K. Trans-4methylcyclohexylamine, a potent new inhibitor of spermidine synthase. Chem Pharm Bull (Tokyo) 36: 3220-3222, 1988.

12. Shirahata A, Morohoshi T, Fukai M, Akatsu F and Samejima K, Putresine or spermidine binding site of aminopropyltransferases and competitive inhibitors. Biochem Pharmacol 41: 205-212, 1991.

13. Woster PM, Black AY, Duff KJ, Coward JR and Pegg AE. Synthesis and biological evaluation of $S$-adenosyl1.12-diamino-3-thio-9-azadodecane, a multisubstrate adduct inhibitor of spermine synthase. $J$ Med Chem 32: $1300-1307,1989$.

14. Pegg AE, Wechter R, Poulin R. Woster PM and Coward JK, Effect of $S$-adenosyl-1,12-diamino-3-thio9-azadodecane, a multisubstrate inhibitor of spermine synthase, on polyamine metabolism in mammalian cells. Biochemistry 28: 8446-8453, 1989.

15. Baillon JG, Kolb $M$ and Mamont PS, Inhibition of mammalian spermine synthase by $\mathrm{N}$-alkylated-1,3diaminopropane derivatives in vitro and in cultured rat hepatoma cells. Eur J Biochem 179: 17-21, 1989.

16. Schnier J, Schwelberger HG, Smit-McBride Z, Kang $\mathrm{HA}$ and Hershey JWM. Translation initiation factor 5A and its hypusine modification are essential for cell viability in the yeast Saccharomyces cerevisiae. Mol Cell Biol 11: 3105-3114, 1991.

17. Byers TL, Ganem B and Pegg AE, Cytostasis induced in L.1210 murine leukemia cells by the $S$-adenosyl-L. methionine decarboxylase inhibitor $5^{\prime}-\{[(Z)$-4-amino2-butenyl|methylamino $\}-5^{\prime}$-deoxyadenosine may be due to hypusine depletion. Biochem $J$ 287: 717-724, 1992.

18. Behe $M$ and Felsenfeld G. Effects of methylation on a synthetic polynucleotide: The $\mathrm{B}-\mathrm{Z}$ transition in poly (dG-m $5 \mathrm{dC}) \cdot \operatorname{poly}\left(\mathrm{dG}-\mathrm{m}^{5} \mathrm{dC}\right)$. Proc Natl Acad Sci USA 78: $1619-1623,1981$.

19. Bloomfield VA and Wilson RW, Interactions of polyamines with polynucleotides. In: Polyamines in Biology and Medicine (Eds. Morris DR and Marton LJ), pp. 183-206. Marcel Dekker. New York, 1981.

20. Porter CW and Bergeron RJ, Enzyme regulation as an approach to interference with polyamine biosynthesisAn alternative to enzyme inhibition. Adv Enzyme Regul 27: 57-79, 1988. 
21. Casero RA and Pegg AE, Spermidine/spermine $N^{1}$. acetyltransferase-the turning point in polyamine metabolism. FASEB J 7: 653-661. 1993.

22. Porter CW, Ganis B, Libby PR and Bergeron RJ, Correlations between polyamine analogue-induced increases in spermidine/spermine $N^{\prime}$-acetyltransferase activity, polyamine pool depletion, and growth inhibition in human melanoma cell lines. Cancer Res 51: $3715-3720,1991$.

23. Casero RA Jr, Celano P, Ervin S.J, Porter CW, Bergeron RJ and Libby PR, Differential induction of spermidine/spermine $N^{\prime}$-acetyltransferase in human lung cancer cells by the bis(ethyl)polyamine analogues. Cancer Res 49: 3829-3833, 1989.

24. Pegg AE, Wechter R, Pakala R and Bergeron RJ, Effect of $N^{1} . N^{12}$-bis(ethyl)spermine and related compounds on growth and polyamine acetylation. content and excretion in human colon tumor cells. $J$ Biol Chem 264: 11744-11749, 1989.

25. Marton LJ, Effects of treatment with DNA-directed cancer chemotherapeutic agents after polyamine depletion. Pharmacol Ther 32: 183-190, 1987.

26. Tofilon PJ, Deen DF and Marton LJ, $\alpha$-Difluoromethylornithine-induced polyamine depletion of 9L tumor cells modifies drug-induced DNA cross-link formation. Science 222: 1132-1135, 1983.

27. Pegg AE and Coward JK, Growth of mammalian cells in the absence of the accumulation of spermine. Biochem Biophys Res Commun 133: 82-89, 1985.

28. Pegg AE, Coward JK, Talekar RR and Secrist JA III. Effects of certain 5 'substituted adenosines on polyamine synthesis: Selective inhibitors of spermine synthase. Biochemistry 25: 4091-4097, 1986.

29. Pegg AE, Wechter $R$ and Pajunen $A$, Increase in $S$ adenosylmethionine decarboxylase activity in SV-3T3 cells treated with $S$-methyl-5'-methylthioadenosine. Biochem J 244: 49-54. 1987.

30. Shantz LM, Holm I, Jänne $O A$ and Pegg AE, Regulation of $S$-adenosylmethionine decarboxylase activity by alteration in the intracellular polyamine content. Biochem J 288: 511-518. 1992.
31. Bradford M, A rapid and sensitive method for the quantitation of microgram quantities of protein utilizing the principle of protein-dye binding. Anal Biochem 72: 248-254, 1976.

32. Hansen MB, Nielsen SE and Berg K, Re-examination and further development of a precise and rapid dye method for measuring cell growth/cell kill. J Immunol Methods 119: 203-210, 1989.

33. Pegg AE, Secrist JA III and Madhubala R, Properties of L1210 cells resistant to $\alpha$-diffuoromethylornithine. Cancer Res 48: 2678-2682, 1988.

34. Autelli R, Stjernborg L, Khomutov A, Khomutov RM and Persson L, Regulation of $S$-adenosylmethionine decarboxylase in L1210 leukemia cells: Studies using an irreversible inhibitor of the enzyme. Eur $J$ Biochem 196: 551-556, 1991.

35. Persson L, Stjernborg L, Holm I and Heby O, Polyamine-mediated control of mammalian $S$-adenosylL-methionine decarboxylase expression: Effects on the content and translational efficiency of the mRNA Biochem Biophys Res Commun 160: 1196-1202, 1989.

36. Pegg AE and Byers TL, Repair of DNA containing $O^{6}$-alkylguanine, FASEB $J$ 6: 2302-2310, 1991

37. Pegg AE, Mammalian $O^{h}$-alkylguanine-DNA alkyltransferase: Regulation and importance in response to alkylating carcinogenesis and therapeutic agents. Cancer Res 50: 6119-6129, 1990.

38. Dolan ME. Moschel RC and Pegg AE, Depletion of mammalian $O^{6}$-alkylguanine-DNA alkyltransferase activity by $O^{h}$-benzylguanine provides a means to evaluate the role of this protein in protection against carcinogenic and therapeutic alkylating agents. Proc Natl Acad Sci USA 87: 5368-5372. 1990.

39. Dolan ME, Mitchell RB, Mummert C, Moschel RC and Pegg AE. Effect of $O^{h}$-benzylguanine analogues on sensitivity of human tumor cells to the cytotoxic effects of alkylating agents. Cancer Res 51 : 3367-3372, 1991

40. Heby $O$ and Persson L, Molecular genetics of polyamine synthesis in eukaryotic cells. Trends Biochem $S_{c i} 15$ : $153-158,1990$. 